Article

\title{
Swedish House Owners' Intentions Towards Renovations: Is there a Market for One-Stop-Shop?
}

\author{
Georgios Pardalis ${ }^{1, *(\mathbb{C})}$, Krushna Mahapatra ${ }^{1}$, Giangiacomo Bravo ${ }^{2}\left(\mathbb{D}\right.$ and Brijesh Mainali ${ }^{1}$ (I) \\ 1 Built Environment \& Energy Technology, Linnaeus University, 35195 Växjö, Sweden \\ 2 Social Studies/Centre for Data Intensive Sciences and Applications, Linnaeus University, \\ 35195 Växjö, Sweden \\ * Correspondence: georgios.pardalis@lnu.se; Tel.: +46-076-083-1876
}

Received: 11 June 2019; Accepted: 4 July 2019; Published: 8 July 2019

\begin{abstract}
In this paper, we examine factors affecting owners' intention for renovation of their detached houses. Furthermore, we analyze their interest in choosing a one-stop-shop (OSS) service for the renovation, even though such a concept is not yet established in Sweden, but emerging in other parts of Europe. Our study is based on responses to an online questionnaire survey of 971 house owners residing in Kronoberg Region in Sweden. About $76 \%$ of the respondents intend to renovate in the near future, with approximately $71 \%$ of them preferring to renovate individual components of their dwelling and 5\% to renovate their whole house in steps. House owners of younger age, higher income, higher education, and those with an interest for environmental issues, were the ones most interested in physical renovations, which improves energy efficiency of the building. For those house owners, one-stop-shop can facilitate the decision-making process, and help them to choose those measures that will improve their quality of life. Approximately $20 \%$ of the respondents had a positive view towards an one-stop-shop, which is an indicator that market for such a service exists. Parameters such as quality of work, cost and energy savings and specification of measures to be adopted are the key for the promotion of one-stop-shop. Additionally, house owners want to have a certain level of involvement in the selection of actors performing the renovation. Moreover, financial incentives, e.g., loans, do not play a significant role for the selection of one-stop-shop, but act as complementary motive for house owners.
\end{abstract}

Keywords: house owners; detached house; renovation; retrofit; energy efficiency; one-stop-shop

\section{Introduction}

The European Union has recently set a new goal of 32.5\% energy efficiency for 2030 compared to the levels of 2005. Efforts towards the improvement of the energy efficiency of the housing stock is essential to the decrease of negative effects of climate change and energy systems objectives [1]. Scenarios for the energy use in buildings show an increase of up to five times by 2100 compared to 2010 [2]. Furthermore, European Union Directives urge member states to develop long-term strategies for investments in building renovations, with a goal that the existing building stock be renovated by $2050[3,4]$.

Sweden has a cross-sectoral target of reducing energy intensity by $20 \%$ between 2008 and 2020 . Especially for the building sector, Sweden has a national goal to reduce energy consumption by $20 \%$ compared to the 1995 level by the year 2020 [5]. The residential sector could be a major contributor to achieve this target, as it is responsible for almost $40 \%$ of the total energy use, with $12 \%$ of it coming from single-family houses [6]. Out of 4.7 million residential dwellings, 51\% (2.4 million) are one- or two-family houses (stand-alone houses or houses divided either vertically or horizontally and designed 
for two families occupying separate apartments), and they account for 293 million square meters of floor area, which is larger than that of multi-family houses [7].

According to Statistics Central Bureau (SCB) in Sweden, $86 \%$ of the one- and two-family dwellings are about 30 years old. They have poor energy standard and are in need of renovation. About $50 \%$ of these houses use direct electricity heating or in combination with air-source heating [8]. Moreover, in these old houses, technical installations are likely to be close to the end of their expected life cycle and need replacement.

Renovations in multi-family dwellings, which are carried out by medium to large contractors, have been in the center of political debate in Sweden [9], and a subject of different studies [10-13]. On the other hand, discussions about the renovations of one or two-family dwellings are falling behind. For those houses, energy efficiency is not the main renovation rationale, but a potential additional benefit in a renovation project [14].

Renovations of kitchen and bathrooms are still the most dominant activities, and usually the return on such an investment is rather low, as it has been found in studies in Germany and some other European countries $[15,16]$. In Sweden, house owners carry out renovations, which in small numbers are related to interventions towards improving energy efficiency (e.g., additional ceiling/wall insulation, change of windows, and installation of an advanced heating system) [17]. The same situation applies to other European countries $[18,19]$, where energy renovations seem not to have become a common practice among house owners.

There is large potential for energy efficiency improvements in house renovations, but that potential is not realized due to various barriers. The existing literature examines the reasons for the "energy efficiency gap" [20,21] and explains investments on products and services would improve energy efficiency levels [22]. Results show that investments on those, at this stage, are low, compared to other investment opportunities available in the market $[23,24]$.

Haavik et al. [25] argued that renovation should be a learning process for house owners, as they become aware of the measures they can or should perform in their dwelling, to improve its overall energy performance. Mahapatra et al. [26] described a full-service renovation concept named One-Stop-Shop (OSS). This concept consists of five phases, namely initial evaluation, thorough analysis, proposal of a set of solutions, coordinated execution of the renovation and quality assurance and continued commissioning of the house. Such a concept guides house owners through all the phases of renovation, allowing the adoption of those measures that will improve the energy performance of the dwelling, while at the same time it offers them a renovated house that satisfies their needs. One-stop-shop as a concept has been proposed or tested as a guide in national contexts, such as Norway [27] and Denmark [28]. In Sweden, one-stop-shop still is a theoretical concept for house renovations [26].

For that purpose, renovations are divided in two categories. Physical renovations, which are renovations related to the improvement of the energy performance of the dwelling, and which often require interventions in the building envelope, and aesthetic renovations, which are related to the aesthetic improvement of the dwelling (new kitchen or bathroom, painting the walls or install new wallpaper, etc.).

There exist several studies on house owners' decision-making towards renovations [29-34]. Each of these studies apply to specific contexts. Therefore, the need to examine country-specific factors affecting house owners' decisions to renovate is important to design intervention measures, as these factors are influenced by the political, economic, social and cultural context of each country. In a previous study [35], we examined factors that influence Swedish house owners' decisions to renovate in the past. The study showed that majority of the households had performed aesthetic renovation in the past and limited households had performed physical renovation in steps. In most cases, house owners would like to tailor the renovation package to their specific wishes providing less importance to the proper sequence and scope of necessary renovation tasks to gain synergy in the entire renovation project [36]. In this paper, we examine the factors affecting Swedish house owners' 
decisions to renovate in the near future in general, and the preferred type of renovation in particular. We are interested in understanding the pathway that leads to the intention/plan for future renovation and to examine if such decisions are influenced by the renovation performed in the past.

The European Commission through the "Smart financing for smart buildings" initiative and through the "new" Energy Performance of Buildings Directive (EPBD) supports one-stop-shop concepts as part of the Directive 2018/844/EU [37]. In this particular directive [4], "Member States are required to facilitate access to appropriate mechanisms for accessible and transparent advisory tools, such as one-stop-shops for consumers and energy advisory services, on relevant energy efficiency renovations and financing instruments." Since one-stop-shop models in the European Union are at an initial stage of market development, it is important to know if a market for that concept exists, and who can be the beneficiaries from this model. Analyzing the potential interest of Swedish house owners on one-stop-shop helps us to acquire knowledge regarding the level of market in the country, and those specific attributes of house owners interested to renovate their dwelling with that model. The results can be used as a guide on a broader European level for the further development of the concept in the future. Moreover, this paper analyzes the potential interest of Swedish house owners on a one-stop-shop concept for renovation.

The study was based on the responses to an online questionnaire survey of 971 house owners in Kronoberg County, focusing on their plans to renovate until 2020. Examining house owners' plans for renovation provided understanding on how these house owners think and the factors that can affect their decisions. Kronoberg County is an interesting setting for this study as it has energy efficiency and sustainability central to its development strategy [38].

\section{Literature Review}

The inadequate adoption of energy efficient measures by the house owners is a subject widely examined in the literature. Several studies identify the factors motivating or preventing house owners from adopting such measures (e.g., [27,29-35,37-41]). In general, the decision of house owners regarding energy efficiency related renovations is the outcome of different factors, which can act either as motives or as barriers for those decisions. Weiss et al. [42] excluded from the agenda potential barriers and motives that have to do with regulatory instruments, as those instruments can be addressed and renewed as long as we understand the broader set of motives and barriers house owners are facing towards performing energy renovations. The rest can be divided into the following broader categories: (1) economic factors; (2) behavioral factors; (3) physical factors related to the house; and (4) social factors. Before examining those different categories, it is important to understand the overall context of renovation decisions.

\subsection{Contexts of Renovation Decisions}

According to Guy and Shove [43], "greater attention should be paid to the changing contexts of energy-related decision making". For energy efficient renovation, these "changing contexts" are closely connected to life at home, or, as Maller and Horne [44] specified it, "the conventions and practices of households" (p61). The decision to renovate and the selection of what needs to be renovated, derives from the need of households to adapt to the changing demands of domestic life. Karvonen [45] claimed that "Domestic retrofit is not an activity of changing a house from poor energy performance to exceptional energy performance, but an intervention into the rhythms of domestic habitation". From a decision-making perspective, households do not consider the adoption of energy efficiency measures as a separate type of renovations. Previous research has found that adoption of energy efficiency measures often is combined with expansions or intensifications of other parts of the dwelling [46]. That can lead us to the conclusion that the decision-making process for a renovation is not something static, but the outcome of a "journey" for house owners leading to the decision of what needs to be done. 
Wilson et al. [47] developed a decision model depicting the decision-making process of each household towards renovations (Figure 1). In this model, the stages of the renovation decision process are "thinking about" (Stage 1), "planning" (Stage 2), and "finalizing" renovations (Stage 3). A final "experiencing" stage describes how households experience and adapt domestic life to the structural changes made to their home. The transition from each stage to the other is affected by factors which are described in the following subsections.

\section{Renovation Decision Process: Conceptual Framework.}

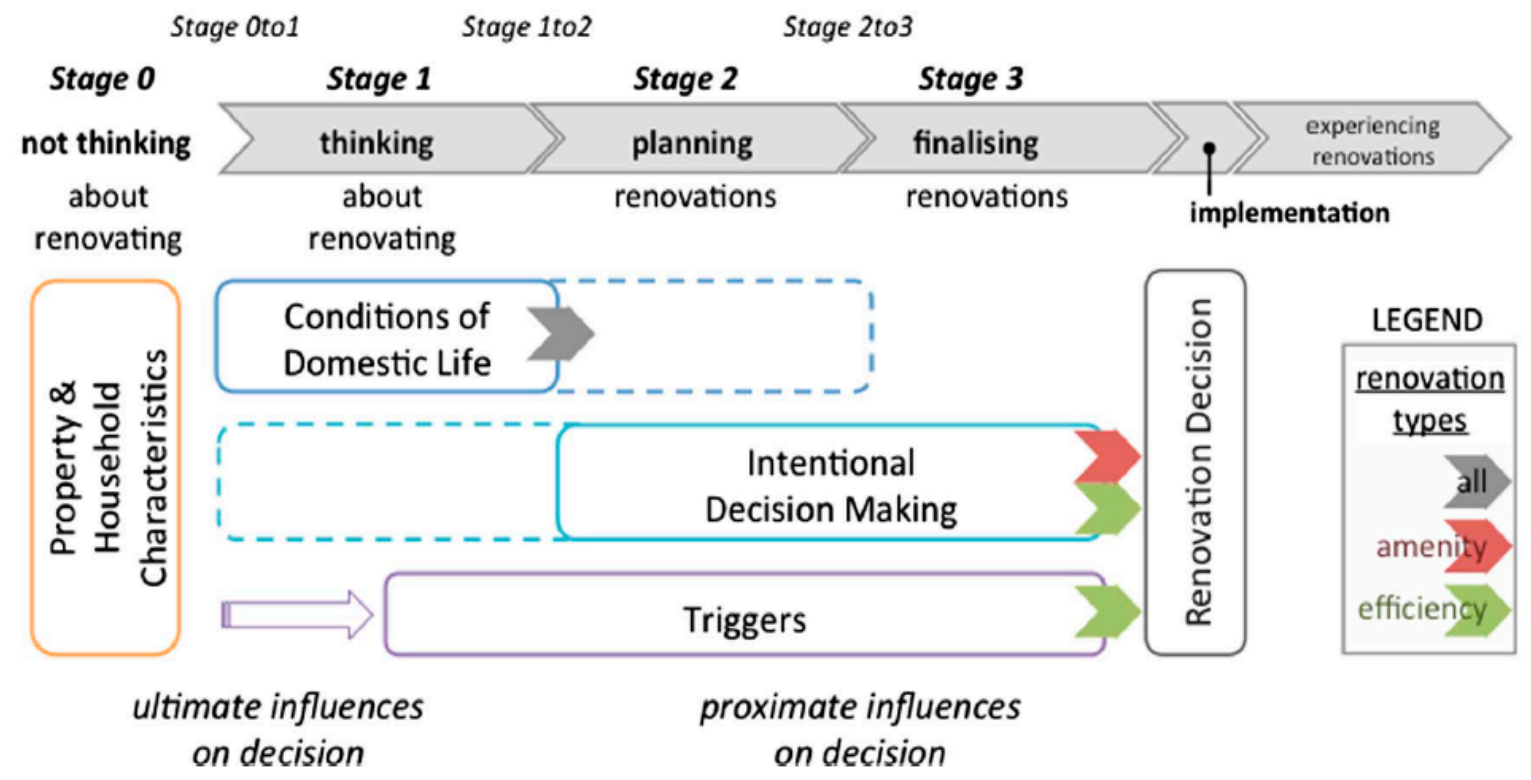

Figure 1. Conceptual framework for renovation decision made in the context of everyday domestic life (retrieved from [47]).

\subsection{Economic Factors}

High cost of investment for energy efficient renovations and the lack of financial resources from house owners' side is the most common preventing factor appearing in studies [31,35,48-52]. There is a need for a significant upfront funding to overcome that barrier [26]. Furthermore, the banking system, and especially the interest rates of loans, have a great impact on the feasibility of renovations. Those households seeking for financial support for a renovation project banks might get demotivated since there is a lack of funding opportunities for such projects, with the existing opportunities not having acceptable terms that could ensure investments in energy efficiency measures [53]. Additionally, transaction costs have been found to affect negatively the renovation decision. Mundaca et al. [54] interpreted it as part of "hidden costs" that have not been adequately considered in the initial cost analysis of a household. Households with higher income are more positively inclined to adopt energy efficient measures, while families with lower income are reluctant to proceed in such an investment [30]. The low-income households, when deciding to perform a renovation, are more likely to perform a more obvious change in their dwelling, such as changing a bathroom or kitchen [55]. The financial returns from an investment in energy efficiency measures is considered another motivating factor for house owners. Many house owners consider that the financial returns from investments in multiple energy efficiency measures are negative [56], while others find a strong motive in their belief that potential energy savings will pay off their initial investment [57]. Those house owners who find a negative relationship between multiple energy efficiency investments and financial returns are more willing to adopt the energy efficiency measures that will bring them short term investment returns, especially if the investment cost for them is modest [58]. For households consuming a vast amount of energy, lowering the energy needs and thus the cost is a significant motive [59]. 


\subsection{Behavioral Factors}

Many studies highlight that the motivations and barriers to individual behaviors have great influence on decision-making $[60,61]$. House owners' decisions to renovate or not, and the type of preferred renovation (physical or aesthetic), are influenced by factors such as environmental awareness, age, lack of awareness or uncertainty regarding which artisans are capable of performing energy renovations, and personal attitude. House owners, who show sensitivity for environmental subjects and show a high level of environmental awareness, are more inclined to adopt energy efficiency measures [62]. Their awareness is also the determining factor of the specific measures they are going to adopt $[31,63]$. Moreover, the feeling that they contribute to a broader goal (e.g., protection of environment) enforces the feeling of fulfillment and motivates them to adopt measures and behaviors towards that direction [64].

Older house owners are usually more able to invest in energy efficiency, preferring however to make the least of changes (e.g., using energy efficient light bulbs), while younger house owners being more probable to actually adopt energy efficient measures [34]. Middle-aged house owners, and especially those having families, despite their willingness to invest in energy efficiency, tend to adopt only the absolutely necessary measures [34]. The perception of house owners regarding the acceptable levels of comfort in their dwelling motivates them to proceed in mediocre energy-efficient renovations, compared to very technical packages of changes proposed, which cannot be fully understood by them [65].

An important factor in the adoption decision is the experience of a renovation in the past. House owners who have performed a renovation, become more aware, and gain the ability to make more rational choices in the measures they need to adopt [17]. Risholt and Barker [27] claimed that house owners' decisions to renovate has a qualitative basis. House owners whose goal is modernizing the look of their dwelling, improve their lifestyle and their behavior as dwellers by simply proceeding with a renovation to change social status [35]. Moreover, it is important for house owners not to be pushed to see energy saving as an individual goal. If energy saving becomes a part of a more integrated process, which includes other improvements on their house, then they are more willing to consider energy efficient solutions $[14,30]$. The availability of trustworthy technical solutions and policies supporting energy efficiency and allowing house owners to benefit from it is a significant motive to renovations of that type [35]. However, the most common barrier for house owners is their lack of awareness regarding availability of competent companies, and trust on them in executing renovations [66]. This barrier is less visible, when house owners deal with professionals that have performed more renovation projects and gained experience $[67,68]$.

\subsection{Physical Factors}

Physical factors are related to the physical condition of the house, such as age, state of the envelope, and needs for extensions or comfort improvements. The later has been found to be a great motive for the decisions of house owners to adopt energy-efficiency measures [31,42,43,46,69-73]. The willingness of house owners to improve the appearance, architecture and generally update the physical context of the property can act as strong motives [14,74].

\subsection{Social Factors}

A supportive social environment (support from family, appreciation by neighbors etc.) increases the motivation of house owners to undertake a renovation project [30]. Especially, for energy related renovations, a supporting social environment has a positive influence on house owners, both on the decision-making process but also during the renovation itself [75]. Another motivation is the presentation of the best practice renovated house to "Future Renovators" [76]. This practice can motivate house owners who have decided to undertake a renovation project to implement more optimized measures and adopt a holistic approach to the renovation project. Additionally, it can act 
as a strong motivational factor even to those house owners who do not have in mind to perform any renovation at all [76]. The best practice approach can also improve the information channels between house owners towards understanding the benefits they can gain from adopting optimized measures [46]. Through those communication channels, they can get trustworthy answers to potentially similar concerns, which made them reluctant to undertake a renovation.

\section{Methods and Data}

The data analyzed in this study was gathered from an online survey of house owners in the Kronoberg Region, Sweden, conducted in late spring 2017. The survey included different sections related to respondents' demographic characteristics, characteristics of their dwelling, past experiences on renovation, plans for renovation up to 2020, and perception towards a holistic service for house renovation among others. The house insurance company Länsförsäkring Kronoberg (the daughter company of Länsförsäkring $\mathrm{AB}$, a Swedish federation of 23 mutual insurance companies owned by the customers) emailed the online questionnaire to 7193 house owners. A total of 971 house owners answered after one reminder. The response rate of $13.5 \%$ is in line with the standards for online surveys [77]. All statistical analyses were performed using the $R 3.4$ platform [78]

To better understand the complex causal relationships among the factors affecting the owners' decisions, we estimated a structural equation model using a partial least square approach, a technique also known as partial least squares path modeling (PLSPM) $[79,80]$. This technique-which has found large application in marketing and tourism studies [81-84] and in construction research [85]—employs rigorous statistical tools [86] to estimate models including complex cause-effect relationships. Models usually comprise both manifest variables and latent constructs, i.e., variables that are not directly observable but can be inferred from the data. More specifically, any PLSPM is built in two steps. First, latent constructs are built from the manifest observations through principal component analysis. Each construct is thought to represent a single "dimension" underlying the observed variables. Then, a network of relations among these constructs is hypothesized, where links are assumed to represent cause-effects processes. The network is formed by one or more starting nodes ("independent" variables only affecting other nodes), one or more intermediate nodes (construct both affecting and being affected by other nodes) and one or more terminal nodes (constructs affected but not affecting other nodes). Finally, the resulting "paths" are estimated quantitatively by considering the overall network as a system of multiple interconnected linear regressions.

\section{Presentation of Findings}

\subsection{Non-Response Bias}

Since only $13.5 \%$ of those surveyed responded, it was important to check that they represent the house owners living in Kronoberg County. Therefore, we compared the distribution of our results with data from the Swedish Statistics Central Bureau (SCB). The distribution in our sample of the age of house owners and the construction year of houses is broadly consistent with data from Statistics Sweden (SCB), even if the number of older houses (i.e., built before 1931) looks somewhat underrepresented (Table 1). On the other hand, the number of houses built between 1961 and 1990 are slightly over-represented, which may have actually made our results more interesting as many of the houses built in that period have low energy standards, but better from similar buildings of an older age, and need to be renovated, and hence represent a crucial target for our purposes. 
Table 1. Distribution (\%) of age of house owners and house construction year in our sample compared to SCB data.

\begin{tabular}{ccccccccc}
\hline $\begin{array}{c}\text { Age Group } \\
\text { (Years) }\end{array}$ & $\mathbf{< 2 9}$ & $\mathbf{3 0 - 3 9}$ & $\mathbf{4 0 - 4 9}$ & $\mathbf{5 0 - 5 9}$ & $\mathbf{6 0 - 6 9}$ & $\mathbf{7 0 - 7 9}$ & $\mathbf{7 9}$ & \\
\hline Survey & 2.69 & 18.29 & 16.05 & $\mathbf{2 0 . 7 6}$ & $\mathbf{2 3 . 2 3}$ & 16.95 & 2.02 & \\
\hline SCB data & 2.45 & 11.61 & 19.14 & 20.83 & 21.05 & 16.90 & 8.03 & \\
\hline Year built & $<1940$ & $1941-1950$ & $1951-1960$ & $1961-1970$ & $1971-1980$ & $1981-1990$ & $1991-1900$ & $>2001$ \\
\hline Survey & 19.53 & 6.65 & 6.54 & 17.24 & 29.91 & 10.18 & 3.84 & 6.13 \\
\hline SCB Data & 31.44 & 7.18 & 8.29 & 15.76 & 22.28 & 6.73 & 2.41 & 5.9 \\
\hline
\end{tabular}

\subsection{Renovation Plans for the Near Future}

Most house owners have planned to renew at least some parts of the house while only a small minority (about $5.5 \%$ of the respondents) declare that they will renew the whole house, in most cases step by step (Figure 2a). Most items to be renewed are related to the aesthetic aspects of the house- such as the kitchen, bathroom or indoor walls—while the windows are the most common item in this list having a significant impact on the building energy consumption (Figure 2b).

(a)

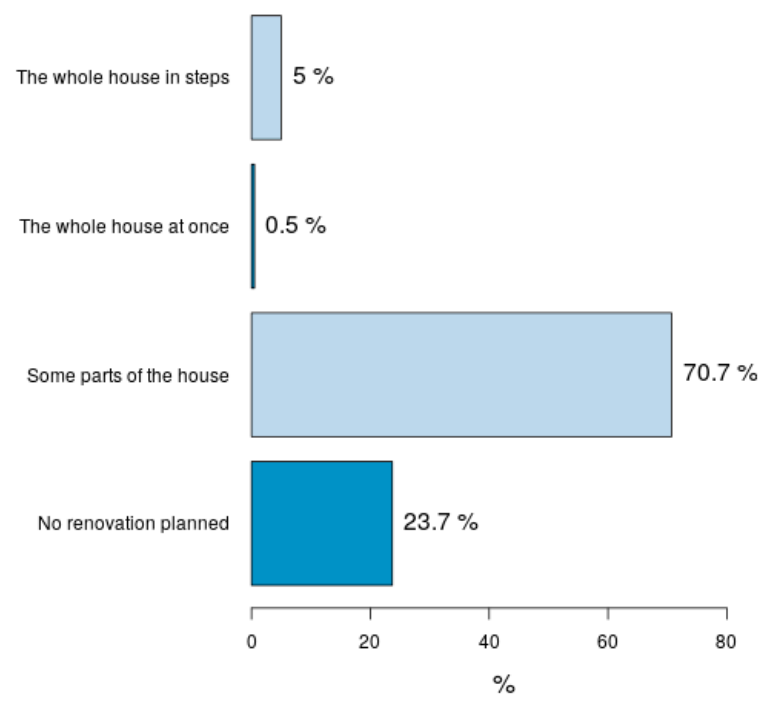

(b)

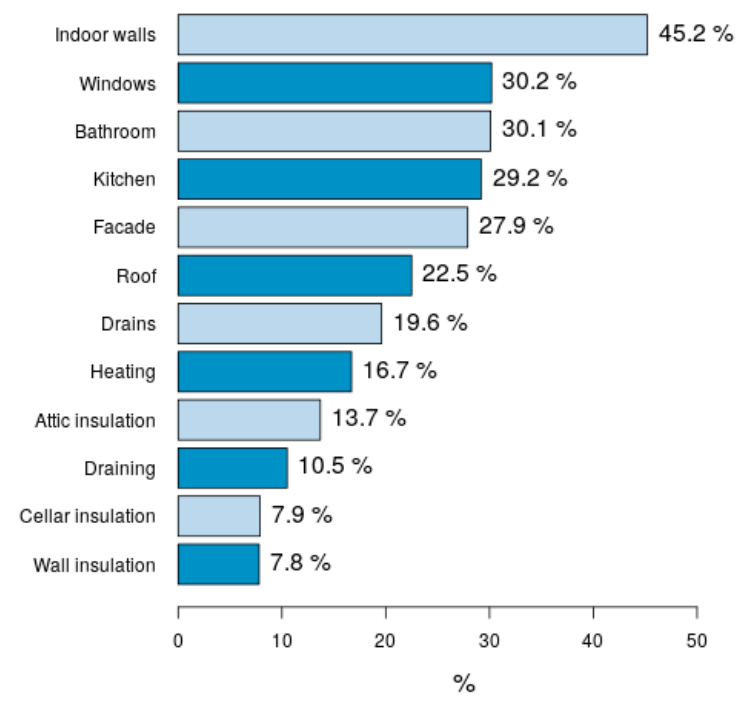

Figure 2. Frequency distribution for the renovation prospects as a whole (a) and the items that respondents are planning to renew $(\mathbf{b})$.

To model the complex causal relationships leading to the decision for renovation, we estimated a PLSPM. The outcomes of interest for our model are latent construct reflecting comfort and physical renovation, respectively. They are supposed to be affected by several variables, both manifest and latent, which are derived from the survey answers. The resulting model structure is shown in Figure 3a, while a description of the variables included in the model is presented below. 


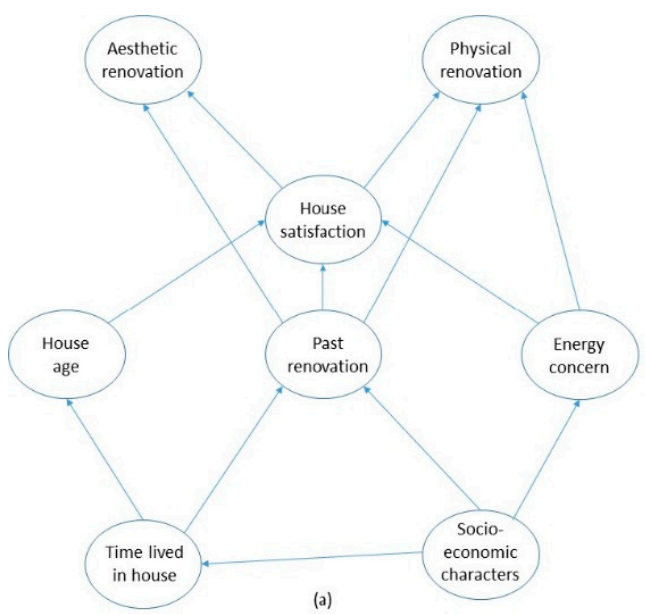

21.05

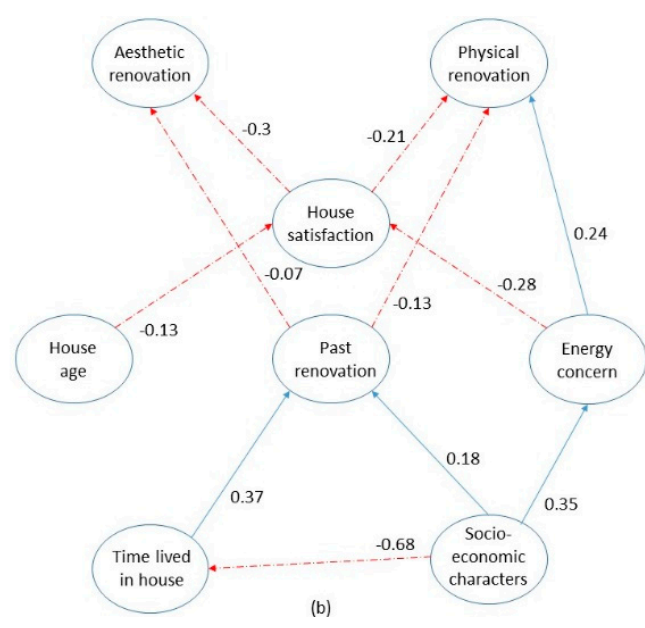

(b)

Figure 3. PLSPM analysis of physical and aesthetic renovation plans: (a) the model structure; and (b) the path coefficient estimates (paths with negative coefficients are dashed, and non-significant paths are omitted).

The time lived in the house, the house age and whether renovation works were performed in the past are included in the model as manifest variables, directly drawn from the survey data. The socioeconomic characteristics is instead a latent configuration based on data about the respondent's age, income and education and takes higher values for younger, higher income and higher education respondents (Dillon-Goldstein's (DG) $r=0.70$; a DG coefficient $\geq 0.7$ is usually considered good, while coefficients $\geq 0.6$ are considered acceptable). The energy concern construct was estimated based on questions about the importance for the house owners to save energy and their willingness to adopt technical and behavioral measures to do so (DG $r=0.79)$. The house satisfaction construct derived from a battery of questions on different aspects concerning the current satisfaction with the house, such as size, aspect, energy costs, etc. (DG $r=0.87$ ). The comfort renovation construct reflects works to renovate the kitchen, bathroom and indoor walls ( $\mathrm{DG} \mathrm{r}=0.80$ ). The physical renovation construct instead reflects works linked to the attic, cellar or wall insulation, draining, windows, roof, facade, drains, and the heating system (DG $\mathrm{r}=0.84$ ).

Figure $4 \mathrm{~b}$ shows the resulting model, with path coefficient estimates, while Table 2 reports the direct, indirect and total effect of each variable. The overall goodness of fit of the model is 0.25 . Bootstrap validation was performed, confirming the robustness of the effect estimates. The physical renovation of the house is affected positively by the socioeconomic characteristics and the energy concern of the respondent, while having already done some renovation in the past and being satisfied with the current house conditions (main effects only) negatively affect it. The comfort renovation of the house is only weakly positively affected by the house age, energy concerns and socioeconomic characteristics, while it is affected negatively by past renovations and, especially, house satisfaction. 
Table 2. Direct, indirect and total effects in the renovation model.

\begin{tabular}{|c|c|c|c|}
\hline Relationships & Direct & Indirect & Total \\
\hline $\begin{array}{c}\text { Socioeconomic characters -> Time lived in } \\
\text { house }\end{array}$ & -0.68 & 0.00 & -0.68 \\
\hline $\begin{array}{c}\text { Socioeconomic characters -> Energy } \\
\text { concern }\end{array}$ & 0.35 & 0.00 & 0.35 \\
\hline $\begin{array}{c}\text { Socioeconomic characters }->\text { Past } \\
\text { renovation }\end{array}$ & 0.18 & -0.25 & -0.08 \\
\hline Socioeconomic characters $->$ House age & 0.00 & -0.002 & -0.02 \\
\hline $\begin{array}{c}\text { Socioeconomic characters }->\text { House } \\
\text { satisfaction }\end{array}$ & 0.00 & -0.09 & -0.09 \\
\hline $\begin{array}{c}\text { Socioeconomic characters -> Physical } \\
\text { renovation }\end{array}$ & 0.00 & 0.11 & 0.11 \\
\hline $\begin{array}{c}\text { Socioeconomic characters -> Aesthetic } \\
\text { renovation }\end{array}$ & 0.00 & 0.03 & 0.03 \\
\hline Time lived in house $->$ Past renovation & 0.37 & 0.00 & 0.37 \\
\hline Time lived in house $->$ House age & 0.02 & 0.00 & 0.02 \\
\hline Time lived in house $->$ House satisfaction & 0.00 & -0.01 & -0.01 \\
\hline Time lived in house -> Physical renovation & 0.00 & -0.04 & -0.04 \\
\hline $\begin{array}{c}\text { Time lived in house }->\text { Aesthetic } \\
\text { renovation }\end{array}$ & 0.00 & -0.02 & -0.02 \\
\hline Energy concern -> House satisfaction & -0.28 & 0.00 & -0.28 \\
\hline Energy concern -> Physical renovation & 0.24 & 0.06 & 0.29 \\
\hline Energy concern -> Aesthetic renovation & 0.00 & 0.08 & 0.08 \\
\hline Past renovation -> House satisfaction & -0.03 & 0.00 & -0.03 \\
\hline Past renovation $->$ Physical renovation & -0.13 & 0.01 & -0.12 \\
\hline Past renovation $->$ Aesthetic renovation & -0.07 & 0.01 & -0.07 \\
\hline House age $->$ House satisfaction & -0.13 & 0.00 & -0.13 \\
\hline House age $->$ Physical renovation & 0.00 & 0.03 & 0.03 \\
\hline House age -> Comfort renovation & 0.00 & 0.04 & 0.04 \\
\hline House satisfaction $->$ Physical renovation & -0.21 & 0.00 & -0.21 \\
\hline House satisfaction $->$ Comfort renovation & -0.30 & 0.00 & -0.30 \\
\hline
\end{tabular}

\subsection{Interest for the One-Stop-Shop (OSS) Concept}

The survey included a question about the interest for energy renovation of the house in the case a single entrepreneur would offer a comprehensive package for the work. The possible responses were coded on a scale from 1 to 5 , where 1 means not at all interested and 5 very interested. About $15 \%$ of the respondents indicated a value of 4 , and $6 \%$ indicated 5 , showing an appreciable interest for the one-stop-shop concept. This $21 \%$ of interested house owners corresponds to the $16 \%$ of innovators/early adopters required for innovation diffusion [87]. The distribution of socioeconomic characteristics of this group shows that middle-aged, high-educated and high-income owners (Table 3) are interested in one-stop-shop.

Among the aspects that the most interested respondents marked as more important for the success of a comprehensive package for energy renovation are the guarantee of the work quality (with an average mark of 4.7/5), clear work costs and estimations of future energy savings (4.6/5) and careful inspections and suggestions before starting the work (4.4/5). The least important aspects instead were the provision of alternative lodging opportunities during the renovation work (2.8/5) and the possibility of getting a loan as part of the package (3.6/5). The respondents that were not interested in one-stop-shop mentioned higher cost (3.4/5) and the freedom to choose different companies for different tasks themselves (3.2/5) as main reasons for their answer.

To understand better the factors affecting the interest for comprehensive energy renovation, we estimated a PLSPM model similar to the one above, although with just one terminal node reflecting the question about the respondents' interests in the one-stop-shop concept (Figure 3a). 
Table 3. Distribution (percentage) of socioeconomic characteristics for high interested respondents.

\begin{tabular}{cccccc}
\hline Age (years) & $<\mathbf{3 0}$ & $\mathbf{3 0 - 5 0}$ & $\mathbf{5 0 - 7 0}$ & $>\mathbf{7 0}$ & \\
\hline \multirow{2}{*}{ Education } & 4.5 & 47.7 & 36.4 & 11.4 & \\
\hline \multirow{2}{*}{ Household income } & Primary school & High school & University & Other & \\
& 8.3 & 35.2 & 55.4 & 1.0 & \\
& \multirow{2}{*}{$* 300 \mathrm{~K}$ SEK } & 300K-400K & 400K-600K & 600K-750K & \multirow{2}{*}{ 750K SEK } \\
\hline & 9.4 & SEK & SEK & SEK & \\
\hline
\end{tabular}

The time lived in the house, the house age and whether renovation works were performed in the past entered the model as manifest variables. The socioeconomic characters (Dillon- Goldstein's $r=0: 70)$, the energy concern (DG $r=0: 79)$ and the house satisfaction (DG $r=0: 87)$ were instead estimated as latent constructs as above.

Figure $4 \mathrm{~b}$ shows the resulting model, with path coefficient estimates, while Table 4 reports the direct, indirect and total effect of each variable. The overall goodness of fit (the "goodness of fit" of a PLSPM is a composite measure taking into account both the capacity of the model to predict the data and the reliability of the latent variables [79]) of the model is 0.25 . Bootstrap validation was performed, confirming the robustness of the effect estimates. The main driver of the interest towards the one-stop-shop concept are the socioeconomic characteristics of the respondent (i.e., being young, highly educated and with a high income) and, to a much lower extent, the age of the house. People who are highly satisfied with the current condition of their current house tend to be less interested in the concept.

Table 4. Direct, indirect and total effects in the one-stop-shop (OSS) model.

\begin{tabular}{|c|c|c|c|}
\hline Relationships & Direct & Indirect & Total \\
\hline $\begin{array}{l}\text { Socioeconomic character. -> Time lived } \\
\text { in house }\end{array}$ & -0.68 & 0.00 & -0.68 \\
\hline $\begin{array}{c}\text { Socioeconomic characters -> Energy } \\
\text { concern }\end{array}$ & 0.35 & 0.00 & 0.35 \\
\hline $\begin{array}{c}\text { Socioeconomic characters }->\text { Past } \\
\text { renovation }\end{array}$ & 0.17 & -0.24 & -0.07 \\
\hline Socioeconomic characters $->$ House age & 0.00 & -0.01 & -0.01 \\
\hline $\begin{array}{c}\text { Socioeconomic characters -> House } \\
\text { satisfaction }\end{array}$ & 0.00 & -0.09 & -0.09 \\
\hline $\begin{array}{c}\text { Socioeconomics characters. -> Interest in } \\
\text { OSS }\end{array}$ & 0.00 & 0.12 & 0.12 \\
\hline Time lived in house -> Past renovation & 0.35 & 0.00 & 0.35 \\
\hline Time lived in house $->$ House age & 0.02 & 0.00 & 0.02 \\
\hline Time lived in house -> House satisfaction & 0.00 & -0.01 & -0.01 \\
\hline Energy concern -> House satisfaction & -0.27 & 0.00 & -0.27 \\
\hline Energy concern -> Interest in OSS & 0.33 & 0.02 & 0.35 \\
\hline Past renovation $->$ House satisfaction & -0.02 & 0.00 & -0.02 \\
\hline House age -> House satisfaction & -0.16 & 0.00 & -0.16 \\
\hline House age -> Interest in OSS & 0.00 & 0.01 & 0.01 \\
\hline House satisfaction -> Interest in OS & -0.09 & 0.00 & -0.09 \\
\hline
\end{tabular}



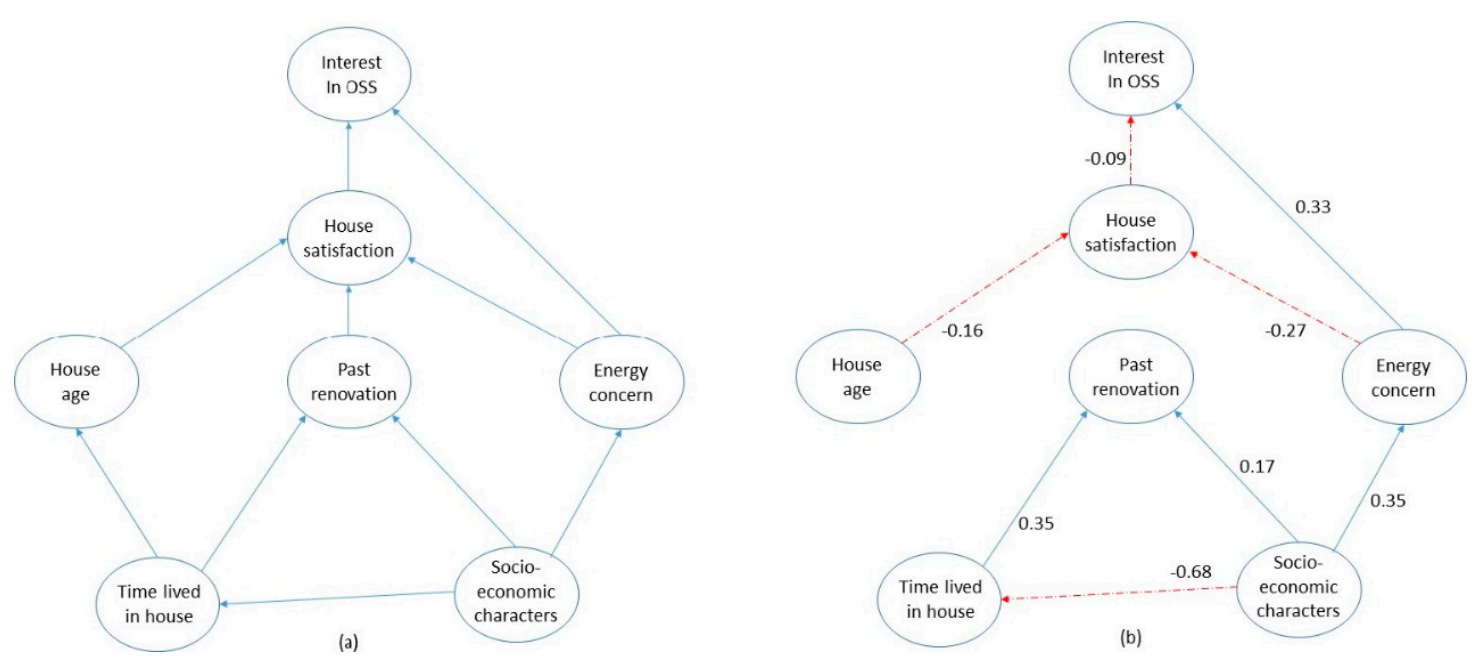

Figure 4. PLSPM analysis of the interest towards the one-stop-shop concept: (a) the model structure; and (b) the path coefficient estimates (paths with negative coefficients are dashed, and non-significant paths are omitted).

\section{Discussion and Conclusions}

This study analyzed the complex casual relationships among several variables leading to house owners planned renovation in the near future, and identified the attributes that positively or negatively affected those decisions. Furthermore, it provided us with information about the attitude of house owners towards a one-stop-shop service for renovations, which includes consulting, independent energy audit, renovation work, independent quality control and commissioning, and financing offered by a single actor. The findings show that more than $50 \%$ of examined house owners were positively inclined to perform a renovation project in their dwellings in the near future. In their majority, they prefer to renovate only individual components of their dwelling. For those planning to renovate their whole house, they preferred to perform such a project following a step wise approach, rather than renovating their house at once.

The analysis shows that, if any kind of renovation (physical or aesthetic) has already been carried out in the past, it negatively influences the decision of house owners to perform any type of renovation in the future. For those who are planning to perform a renovation in the future, the plan is to renovate only individual components of their dwelling addressing the immediate needs of their household.

House owners with higher income and higher education are more inclined towards performing physical renovations that improve the energy performance of the house. Additionally, those house owners are of younger age, and they show interest for the environment. Their interest on the environment was found to be an important motive for them, and it is an indicator to show that their decision to adopt energy efficient measures is connected to a broader environmental protection goal. On the other hand, satisfaction of house owners with the current state of their dwelling is an attribute that negatively affects their decision to perform a renovation in the future. That satisfaction can possibly derive from the outcomes of a previously performed renovation.

Our findings show that the age of the house affects positively, yet weakly, the decisions of house owners to perform changes that will improve the aesthetics and comfort of their dwelling. Such a decision is further connected to the energy concerns of the owners, as well as their financial capacity, age and educational level.

The one-stop-shop concept for the renovation of single-family houses that presently does not exist in Sweden. Answers regarding intention on the hypothetical one-stop-shop concept showed that 21\% of the respondents have a significant interest for this concept. This segment consists of middle-aged house owners (aged 30-50), with higher income and high-level of education. The age of the house did 
not have significant influence on the decision on one-stop-shop. Again, those house owners who are satisfied with the condition of their dwelling show no interest in such a concept.

For those house owners interested in one-stop-shop, it can facilitate their renovation decision process. By considering the individual characteristics of each household and the socio-economic conditions of household, one-stop-shop can offer customized renovation package solutions with proper sequencing adopting the necessary measures to improve their quality of life, and enable them to perform physical or deep renovation in steps.

Those respondents who showed interest for one-stop-shop posed some interesting arguments that could act as guidelines for the further development of this concept. Parameters such as the quality of work, clearly defined costs and energy savings and the suggestion of specific measures to adopt play an important role towards deciding to buy such a service. Financial incentives, for example loans, were considered as of lower importance for those interested in one-stop-shop. Such loans however could act as a motive for house owners who are yet unsure of choosing an one-stop-shop for the renovation of their dwelling, and the role of such a financial incentive need to be further examined. Another parameter that could be the subject of further research for the development of a one-stop-shop concept relates to the expressed desire of house owners to be able to choose the different companies that will perform the renovation works. The level of their involvement on one-stop-shop and how this could affect the final renovation could be further researched.

This study has some limitations. The potential of self-selection bias in the analysis exists with respect to aspects that have not been taken under consideration. Additionally, since the analyzed sample consists of house owners living in Kronoberg Region, it reflects the perceptions within this specific geographic area, which may be different to those of people living in other regions in Sweden. Furthermore, we need to consider that house owners were asked to express their interest in a concept that presently does not exist in the Swedish market.

To sum up, the process leading to the decision for renovation in the future is the product of several variable interacting with each other to the outcome. Taking into account the multiple factors affecting such a decision, we have identified a target group, consisting of house owners aged between 30 and 50 years of age, with university education and medium-high and high income, which has a higher inclination to adopt energy efficiency measures in the renovation of their dwelling. That same group also shows significant interest for one-stop-shop renovation services for their dwelling. Financial incentives and participatory acts from house owners' side can increase the interest for one-stop-shop. Those can be the subject of study for policy-makers to manage to mobilize more house owners to the direction of energy efficiency, achieving that way the realization of a part of national goals for environment in the future. Moreover, even though the analysis concerned a sample of house owners living at a specific geographical area, we were able to extract statistically strong results, providing interesting insights about house owners' plans for renovation, and their perceptions over a holistic service for that renovation, which could be relevant for international audiences.

Author Contributions: Conceptualization, G.P., K.M. and B.M.; Questionnaire preparation and online survey, K.M., G.B. and G.P.; Methodology, G.P. and G.B.; Statistical analysis, G.B. and G.P.; writing-original draft preparation, G.P.; review and editing of the manuscript, G.P., K.M., B.M. and G.B.; Visualization, G.P. and G.B.; supervision, K.M.; and project administration, G.P., K.M. and B.M.

Funding: The authors gratefully acknowledge the financial support from the Kamprad Family Foundation for Entrepreneurship, Research \& Charity, Smarthousing Småland, and European Union Horizon 2020 project "INNOVATE". They would also like to thank Länsförsäkring Kronoberg for sharing the questionnaire among its clients, and the survey respondents for responding to the survey.

Conflicts of Interest: The authors declare no conflict of interest.

\section{References}

1. Birol, F. World Energy Outlook Special Report 2013: Redrawing the Energy-Climate Map; IEA: Paris, France, 2013. 
2. Levesque, A.; Pietzcker, R.; Baumstark, L.; Luderer, G. How will buildings' energy demand look in 2100? Quantifying future energy service demand from buildings. In European Council for an Energy Efficient Economy (ECEEE) Summer Study; ECEEE: Hyeres, France, 2017.

3. Directive, E.E. Directive 2012/27/EU of the European Parliament and of the Council of 25 October 2012 on energy efficiency, amending Directives 2009/125/EC and 2010/30/EU and repealing Directives 2004/8/EC and 2006/32. Off. J. 2012, L315, 1-56.

4. European Commission. Directive 2018/844/EU of the European Parliament and of the Council of 30 May 2018 on the energy performance of buildings (amending Directive 2010/31/EU). Off. J. Eur. Union 2018, L156, 75-91.

5. Energimyndigheten. Renovera Energismart; Energimyndigheten: Eskilstuna, Sweden, 2012.

6. Swedish Energy Agency. Energy in Sweden: Facts and Figures. 2017. Available online: http://www. energimyndigheten.se/en/facts-and-figures/publications/ (accessed on 16 February 2019).

7. Swedish Energy Agency. Summary of Energy Statistics for Dwellings and Non-Residential Premises for 2014 (1654-7543). 2015. Available online: www.energimyndigheten.se (accessed on 11 November 2018).

8. Sköldberg, H.; Ryden, B. The Heating Market in Sweden-an Overall View; Sverige Värmemarknad: Stockholm, Sweden, 2014.

9. SABO. Home for Millions: Conditions for Renovation of the Million-Year-Record-Years' Housing; KTH: Stockholm, Sweden, 2009.

10. Stenberg, E. Recycle the Million Program-Individual Solutions for All. In Urbanism: Today's Urban Construction in Rhetoric and Practice; Nordic Academic Press: Lund, Sweden, 2016.

11. Elsinga, M.; Lind, H. The effect of EU-legislation on rental systems in Sweden and the Netherlands. Hous. Stud. 2013, 28, 960-970. [CrossRef]

12. Johansson, P.; Femenías, P.; Thuvander, L.; Wahlgren, P. Pending for renovations: Understanding the conditions of the multi-family housing stock from before 1945. Energy Procedia 2016, 96, 170-179. [CrossRef]

13. Gustafsson, M. Energy Efficient Renovation Strategies for Swedish and Other European Residential and Office Buildings. Ph.D. Thesis, KTH Royal Institute of Technology, Stockholm, Sweden, 2017.

14. Gram-Hanssen, K. Existing buildings-Users, renovations and energy policy. Renew. Energy 2014, 61, 136-140. [CrossRef]

15. Galvin, R. Why German homeowners are reluctant to retrofit. Build. Res. Inf. 2014, 42, 398-408. [CrossRef]

16. Meijer, F.; Itard, L.; Sunikka-Blank, M. Comparing European residential building stocks: Performance, renovation and policy opportunities. Build. Res. Inf. 2009, 37, 533-551. [CrossRef]

17. Nair, G. Implementation of Energy Efficiency Measures in Swedish Single-Family Houses. Ph.D. Thesis, Mid Sweden University, Östersund, Sweden, 2012.

18. Bartiaux, F.; Gram-Hanssen, K.; Fonseca, P.; Ozolina, L.; Christensen, T.H. A practice-theory approach to homeowners' energy retrofits in four European areas. Build. Res. Inf. 2014, 42, 525-538. [CrossRef]

19. Galvin, R.; Sunikka-Blank, M. The UK homeowner-retrofitter as an innovator in a socio-technical system. Energy Policy 2014, 74, 655-662. [CrossRef]

20. World Business Council for Sustainable Development. Energy Efficiency in Buildings. Business Realities and Opportunities; Worls Business Council for Sustainable Development: Geneva, Switzerland, 2010.

21. World Energy Council. Energy Efficiency: A Recipe for Success; World Energy Council: London, UK, 2010.

22. Jaffe, A.B.; Stavins, R.N. The energy-efficiency gap What does it mean? Energy Policy 1994, 22, 804-810. [CrossRef]

23. Sorrell, S.; O'Malley, E.; Schleich, J.; Scott, S. The Economics of Energy Efficiency: Barriers to Cost-Effective Investment. Energy Stud. Rev. 2006, 14, 186.

24. Reddy, B.S. Barriers and drivers to energy efficiency-A new taxonomical approach. Energy Convers. Manag. 2013, 74, 403-416. [CrossRef]

25. Haavik, T.; Tommerup, H.M.; Vanhoutteghem, L.; Svendsen, S.; Paiho, S.; Ala-Juusela, M.; Mahapatra, K.; Gustavsson, L.; Aabrekk, S.E. Renovation of single-family houses-an emerging market. In Proceedings of the SB10 Finland Sustainable Building Conference: Sustainable Community-building SMART, Espoo, Finland, 22-24 September 2010.

26. Mahapatra, K.; Gustavsson, L.; Haavik, T.; Aabrekk, S.; Svendsen, S.; Vanhoutteghem, L.; Paiho, S.; Ala-Juusela, M. Business models for full service energy renovation of single-family houses in Nordic countries. Appl. Energy 2013, 112, 1558-1565. [CrossRef] 
27. Risholt, B.; Berker, T. Success for energy efficient renovation of dwellings-learning from private homeowners. Energy Policy 2013, 61, 1022-1030. [CrossRef]

28. Bjørneboe, M.G.; Svendsen, S.; Heller, A. Using a One-Stop-Shop Concept to Guide Decisions When Single-Family Houses Are Renovated. J. Archit. Eng. 2017, 23, 05017001. [CrossRef]

29. Bravo, G.; Pardalis, G.; Mahapatra, K.; Mainali, B. Physical vs. Aesthetic Renovations: Learning from Swedish House Owners. Buildings 2019, 9, 12. [CrossRef]

30. Baumhof, R.; Decker, T.; Röder, H.; Menrad, K. Which factors determine the extent of house owners' energy-related refurbishment projects? A Motivation-Opportunity-Ability Approach. Sustain. Cities Soc. 2018, 36, 33-41. [CrossRef]

31. Achtnicht, M.; Madlener, R. Factors influencing German house owners' preferences on energy retrofits. Energy Policy 2014, 68, 254-263. [CrossRef]

32. Abreu, M.I.; Oliveira, R.; Lopes, J. Attitudes and practices of homeowners in the decision-making process for building energy renovation. Procedia Eng. 2017, 172, 52-59. [CrossRef]

33. Kløckner, C.; Sopha, B.M.; Matthies, E.; Bjørnstad, E. Energy efficiency in Norwegian households-identifying motivators and barriers with a focus group approach. Int. J. Environ. Sustain. Dev. 2013, 12, 396-415. [CrossRef]

34. Das, R.; Richman, R.; Brown, C. Demographic determinants of Canada households' adoption of energy efficiency measures: Observations from the Households and Environment Survey, 2013. Energy Effic. 2018, 11, 465-482. [CrossRef]

35. Bjørneboe, M.G.; Svendsen, S.; Heller, A. Initiatives for the energy renovation of single-family houses in Denmark evaluated on the basis of barriers and motivators. Energy Build. 2018, 167, 347-358. [CrossRef]

36. Pomianowski, M.; Antonov, Y.I.; Heiselberg, P. Development of energy renovation packages for the Danish residential sector. Energy Procedia 2019, 158, 2847-2852. [CrossRef]

37. Benigna, Bo.; Paolo, B. One-Stop-Shops for Energy Renovations of Buildings; European Commission: Ispra, Italy, 2018.

38. Energikontor Sydost. Climate and Energy Strategy for Kronoberg County and the Region of Southern Småland; Energikontor Sydost: Växjö, Sweden, 2010.

39. Friege, J.; Chappin, E. Modelling decisions on energy-efficient renovations: A review. Renew. Sustain. Energy Rev. 2014, 39, 196-208. [CrossRef]

40. Jakob, M. The Drivers of and Barriers to Energy Efficiency in Renovation Decisions of Single-Family Home-Owners; Center for Energy Policy and Economics CEPE, Department of Management, Technology and Economics: ETH Zurich, Switzerland, 2007; Available online: http://www.cepe.ethz.ch/publications/workingPapers/ CEPE_WP56.pdf (accessed on 29 August 2018).

41. Ebrahimi, S.; Qian, Q.K.; Meijer, F.M.; Visscher, H.J. Unravelling Dutch homeowners' behaviour towards energy efficiency renovations: What drives and hinders their decision-making? Energy Policy 2019, $129,546-561$.

42. Weiss, J.; Dunkelberg, E.; Vogelpohl, T. Improving policy instruments to better tap into homeowner refurbishment potential: Lessons learned from a case study in Germany. Energy Policy 2012, 44, 406-415. [CrossRef]

43. Guy, S.; Shove, E. The Sociology of Energy, Buildings and the Environment: Constructing Knowledge, Designing Practice; Routledge: Abingdon, UK, 2014.

44. Maller, C.J.; Horne, R.E. Living lightly: How does climate change feature in residential home improvements and what are the implications for policy? Urban Policy Res. 2011, 29, 59-72. [CrossRef]

45. Karvonen, A. Towards systemic domestic retrofit: A social practices approach. Build. Res. Inf. 2013, 41, 563-574. [CrossRef]

46. Judson, E.P.; Maller, C. Housing renovations and energy efficiency: Insights from homeowners' practices. Build. Res. Inf. 2014, 42, 501-511. [CrossRef]

47. Wilson, C.; Pettifor, H.; Chryssochoidis, G. Quantitative modelling of why and how homeowners decide to renovate energy efficiently. Appl. Energy 2018, 212, 1333-1344. [CrossRef]

48. Gamtessa, S.F. An explanation of residential energy-efficiency retrofit behavior in Canada. Energy Build. 2013, 57, 155-164. [CrossRef]

49. Alberini, A.; Banfi, S.; Ramseier, C. Energy efficiency investments in the home: Swiss homeowners and expectations about future energy prices. Energy J. 2013, 34, 49-86. [CrossRef] 
50. Banfi, S.; Farsi, M.; Filippini, M.; Jakob, M. Willingness to pay for energy-saving measures in residential buildings. Energy Econ. 2008, 30, 503-516. [CrossRef]

51. Grösche, P.; Schmidt, C.M.; Vance, C. Identifying free-riding in home renovation programs using revealed preference data. Jahrbücher Natl. Stat. 2013, 233, 600-618. [CrossRef]

52. Palmer, K.; Walls, M.; Gordon, H.; Gerarden, T. Assessing the energy-efficiency information gap: Results from a survey of home energy auditors. Energy Effic. 2013, 6, 271-292. [CrossRef]

53. Murphy, L.C. 2016. Policy instruments to improve energy performance of existing owner-occupied dwellings. A+BE| Archit. Built Environ. 2016, 17, 1-242.

54. Mundaca, T.L.; Mansoz, M.; Neij, L.; Timilsina, G.R. Transaction costs analysis of low-carbon technologies. Clim. Policy 2013, 13, 490-513. [CrossRef]

55. März, S. Beyond economics-Understanding the decision-making of German small private landlords in terms of energy efficiency investment. Energy Effic. 2018, 11, 1721-1743. [CrossRef]

56. Friedman, C.; Becker, N.; Erell, E. Retrofitting residential building envelopes for energy efficiency: Motivations of individual homeowners in Israel. J. Environ. Plan. Manag. 2018, 61, 1805-1827. [CrossRef]

57. Salo, M.; Nissinen, A.; Lilja, R.; Olkanen, E.; O'Neill, M.; Uotinen, M. Tailored advice and services to enhance sustainable household consumption in Finland. J. Clean. Prod. 2016, 121, 200-207. [CrossRef]

58. Nair, G.; Gustavsson, L.; Mahapatra, K. Factors influencing energy efficiency investments in existing Swedish residential buildings. Energy Policy 2010, 38, 2956-2963. [CrossRef]

59. Kahneman, D. Maps of bounded rationality: Psychology for behavioral economics. Am. Econ. Rev. 2003, 93, 1449-1475. [CrossRef]

60. Wilson, C.; Dowlatabadi, H. Models of decision making and residential energy use. Annu. Rev. Environ. Resour. 2007, 32, 169-203. [CrossRef]

61. Ameli, N.; Brandt, N. Determinants of households' investment in energy efficiency and renewables: Evidence from the OECD survey on household environmental behaviour and attitudes. Environ. Res. Lett. 2015, 10, 044015. [CrossRef]

62. Achtnicht, M. Do environmental benefits matter? Evidence from a choice experiment among house owners in Germany. Ecol. Econ. 2011, 70, 2191-2200. [CrossRef]

63. Earl, P.E.; Peng, T.C. 10 Home improvements. In Handbook on the Economics of Leisure; Edward Elgar Publishing: Cheltenham, UK, 2011; p. 197.

64. Murphy, L. The influence of energy audits on the energy efficiency investments of private owner-occupied households in the Netherlands. Energy Policy 2014, 65, 398-407. [CrossRef]

65. Buser, M.; Carlsson, V. What you see is not what you get: Single-family house renovation and energy retrofit seen through the lens of sociomateriality. Constr. Manag. Econ. 2017, 35, 276-287. [CrossRef]

66. Fan, K.; Qian, Q.K.; Chan, E.H. Transaction Costs (TCs) in Building Regulations and Control for Green Buildings: Case Study of Hong Kong. Creat. Built Environ. New Oppor. 2016, 1, 818.

67. Hongjuan Wu Qian Queen, K.; Visscher Henk Straub, A. Improving the Supply Chain of Housing Industrialization from Transaction Costs Perspective. In Proceedings of the World Sustainable Built Environment Conference (WSBE17), Hong Kong, 5-7 June 2017; pp. 2792-2797.

68. Frondel, M.; Vance, C. Heterogeneity in the effect of home energy audits: Theory and evidence. Environ. Resour. Econ. 2013, 55, 407-418. [CrossRef]

69. Wilson, C.; Crane, L.; Chryssochoidis, G. Why do homeowners renovate energy efficiently? Contrasting perspectives and implications for policy. Energy Res. Soc. Sci. 2015, 7, 12-22. [CrossRef]

70. Christensen, T.H.; Gram-Hanssen, K.; de Best-Waldhober, M.; Adjei, A. Energy retrofits of Danish homes: Is the Energy Performance Certificate useful? Build. Res. Inf. 2014, 42, 489-500. [CrossRef]

71. Nauleau, M.L. Free-riding on tax credits for home insulation in France: An econometric assessment using panel data. Energy Econ. 2014, 46, 78-92. [CrossRef]

72. Baumhof, R.; Decker, T.; Röder, H.; Menrad, K. An expectancy theory approach: What motivates and differentiates German house owners in the context of energy efficient refurbishment measures? Energy Build. 2017, 152, 483-491. [CrossRef]

73. Zundel, S.; Stieß, I. Beyond profitability of energy-saving measures-Attitudes towards energy saving. J. Consum. Policy 2011, 34, 91-105. [CrossRef]

74. Parnell, R.; Larsen, O.P. Informing the development of domestic energy efficiency initiatives: An everyday householder-centered framework. Environ. Behav. 2005, 37, 787-807. [CrossRef] 
75. Mlecnik, E.; Cre, J.; Kondratenko, I.; Hilderson, W. Innovations in very low energy retrofit projects. In Proceedings of the PLEA 27th Conference on Passive and Low Energy Architecture, Louvain-la-Neuve, Belgium, 13-15 July 2011; pp. 601-606.

76. Mahapatra, K.; Gustavsson, L.; Haavik, T.; Aabrekk, S.; Tommerup, H.M.; Svendsen, S.; Paiho, S.; Ala-Juusela, M. Possible Financing Schemes for One-Stop-Shop Service for Sustainable Renovation of Single-Family Houses; Nordic Innovation Centre: Oslo, Norway, 2011.

77. Baruch, Y.; Holtom, B.C. Survey response rate levels and trends in organizational research. Hum. Relat. 2008, 61, 1139-1160. [CrossRef]

78. Team, R.C. R: A Language and Environment for Statistical Computing; R Foundation for Statistical Computing: Vienna, Austria, 2018; Available online: https://www.R-project.org/ (accessed on 12 March 2019).

79. Esposito Vinzi, V.; Russolillo, G. Partial least squares algorithms and methods. Wiley Interdiscip. Rev. Comput. Stat. 2013, 5, 1-19. [CrossRef]

80. Lohmöller, J.B. Latent Variable Path Modeling with Partial Least Squares; Springer Science \& Business Media: Berlin, Germany, 2013.

81. Hair, J.F.; Sarstedt, M.; Ringle, C.M.; Mena, J.A. An assessment of the use of partial least squares structural equation modeling in marketing research. J. Acad. Mark. Sci. 2012, 40, 414-433. [CrossRef]

82. Wong, K.K.K. Partial least squares structural equation modeling (PLS-SEM) techniques using SmartPLS. Mark. Bull. 2013, 24, 1-32.

83. Sarstedt, M.; Ringle, C.M.; Hair, J.F. Partial least squares structural equation modeling. In Handbook of Market Research; Springer International Publishing: New York, NY, USA, 2017; pp. 1-40.

84. Do Valle, P.O.; Assaker, G. Using partial least squares structural equation modeling in tourism research: A review of past research and recommendations for future applications. J. Travel Res. 2016, 55, 695-708. [CrossRef]

85. Xiong, B.; Skitmore, M.; Xia, B. A critical review of structural equation modeling applications in construction research. Autom. Constr. 2015, 49, 59-70. [CrossRef]

86. Afthanorhan, W.M.A.B.W. A comparison of partial least square structural equation modeling (PLS-SEM) and covariance based structural equation modeling (CB-SEM) for confirmatory factor analysis. Int. J. Eng. Sci. Innov. Technol. 2013, 2, 198-205.

87. Rogers, E.M. Diffusion of Innovations, 5th ed.; Free Press: New York, NY, USA, 2005. 